\title{
RETHINKING THE RELATIONSHIP BETWEEN HOUSING PRICES AND INFLATION: NEW EVIDENCE FROM 29 LARGE CITIES IN CHINA
}

\author{
Jianli TANG (D), Kunhui YE, Yan QIAN \\ School of Construction Management and Real Estate, Chongqing University, Chongqing, China
}

Received 29 March 2018; accepted 14 November 2018

\begin{abstract}
This paper presents a longitudinal analysis of the relationship between housing prices and inflation by employing new housing price indices from 29 large Chinese cities over the 2003-2013 period. Based on the Autoregressive Distributive Lag (ARDL) model and bounds test, we find no long-run co-integration relationship between housing prices and inflation. This result is robust for different types of inflation (actual, expected, unexpected inflation). Furthermore, it is found that the housing prices in China grow spectacularly in the sample period owing to the dramatic development of the Chinese economy, while inflation grows in a more modest way. Although the study is conducted in the context of China, the results can provide useful evidence to the debate on the relationship between housing prices and inflation.
\end{abstract}

Keywords: housing price index, inflation, consumer price index, unit root tests, ARDL model, bounds test.

\section{Introduction}

In China, with the acceleration of the market economy development, the past two decades have witnessed rapid growth of the real estate industry, which is characterized by a long-term increase in housing prices. Specifically, the market value of the residential real estate in 2016 was estimated at $\$ 31.41$ trillion $^{1}, 2.81$ times the 2016 GDP of $\$ 11.19$ trillion $^{2}$, while in 2000 , it is estimated at $\$ 1.11$ trillion, 0.92 times the 2000 GDP of $\$ 1.21$ trillion. The ratio of residential property value to GDP increased by 1.89 times, suggesting that real estate has become an essential part of China's economy and an important sector in maintaining stable economic growth. Accordingly, real estate, especially housing property, is the most popular form of China's household wealth. Due to the appreciation of property and the need to secure returns on investment, private capital tends to flow into real estate markets. Such a tendency continues to push up housing prices. As Figure 1 shows, the average annual increase in real estate

\footnotetext{
1 The data come from the National Bureau of Statistics of China (NBSC). The market value of residential real estate is estimated based on the average residential building area, the urban population and the average price of residential real estate.

2 The data come from the NBSC.
}

prices $^{3}$ in China was $7.83 \%$ from 1998 to $2016^{4}$. With the growth of the whole economy, household income, saving, and consumption in China have been steadily ascending, which resulted in a modest increase in inflation. The average growth of inflation is around $1.94 \%$ per annum.

The upturn development of housing prices has caused citizens to pay closer attention to housing price movements, development trends, and the capacity to maintain and increase the market value of properties. Meanwhile, inflation risk is regarded as one of the major concerns for most property investors to reduce the real value of returns (Larsen \& Sommervoll, 2004). Under the currently increasing pressure on all product prices, a comprehensive and accurate understanding of the relationship between real estate and inflation, including the ability of real estate to resist inflation, will help improve urban residents' household financial management decision-making. Reversely, if this relationship is poorly comprehended, they might fail to know where housing prices will go next and why the prices should go that way. Therefore, a rigorous perception of the relationship between housing prices and

\footnotetext{
3 The data are average housing prices and are retrieved from the NBSC.

4 Inflation is represented by CPI.
}

*Corresponding author. E-mail: tangjianli@cqu.edu.cn 


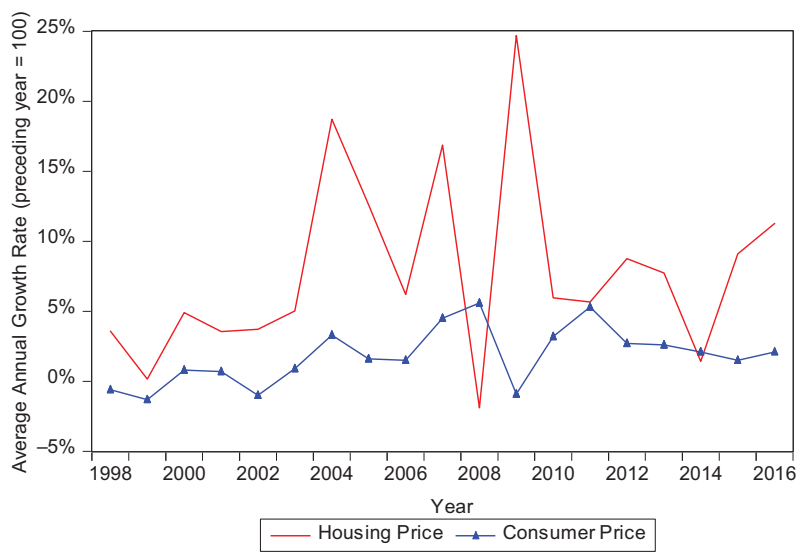

Figure 1. Average annual growth rate of housing and consumer price in China

Note: Rates are calculated based on statistics published by the National Bureau of Statistics of China.

inflation has become a matter of concern for investors, consumers, and researchers.

Many empirical studies have attempted to answer the questions of whether housing prices are cointegrated with inflation and whether real estate provides a good hedge against inflation since the study of Fama and Schwert (1977). However, empirical results are mixed. Some studies (see Ibbotson \& Siegel, 1984; Anari \& Kolari, 2002; Ma \& Liu, 2008) have found that housing prices are closely related to inflation, and real estate offers a stable inflation hedge. Additionally, evidence of the close correlation is also supported by other studies (see Amonhaemanon, De Ceuster, Annaert, \& Le Long, 2013; Bond \& Seiler, 1998; Christou, Gupta, Nyakabawo, \& Wohar, 2018; Hoesli, 1994; Sing \& Low, 2000) when actual inflation is divided into expected and unexpected inflation. Hoesli, MacGregor, Matysiak, and Nanthakumaran (1997) found that real estate might act as somewhat of a hedge against expected inflation and might not offer protection against unexpected inflation in the short term. More recently, Christou et al. (2018) examined the long-run relationship between housing prices and non-housing CPI over the monthly period 1953-2016 in the US using quantile cointegration analysis. The results suggested a co-integration relationship between CPI and HPI series at lower quantiles and no long-run relationship at middle and upper quantiles.

Other research show that there is no cointegrated relationship between housing prices and inflation. For instance, $\mathrm{Li}$ and Ge (2008) insisted there was no relationship between real estate and inflation. Glascock, Feng, Fan, and Bao (2010) found that the Hong Kong housing property market did not provide a hedge against actual, expected and unexpected inflation during the period of 1997-2005 by using the OLS model.

The empirical results in the Chinese real estate market are also mixed. For instance, Kuang and Liu (2015) found housing prices were related to inflation in a positive way based on the panel data of 35 major cities from 1996 to 2010. However, Qiu (2011) found evidence of positive correlation between housing prices and inflation only in the short term, but not in the long run. Some studies focus on the hedging effectiveness of different regions. For example, Wu and Tidwell (2015) explored inflation hedging effectiveness of Chinese eastern, middle, and western real estate markets based on PVAR models. They found very limited hedging effectiveness of the Chinese real estate markets for inflation and among the three regions, the middle real estate market offered comparatively better hedge. Yu and Huang (2016) concluded that the central and western cities in China responded to the change of HPI more obviously than eastern cities or a particular first-tier city. ${ }^{5}$

Thus, clearly the conclusions drawn from prior research on the relationship between housing prices and inflation are inconsistent with each other. One of the primary reasons is the use of different methods. For instance, some researchers employ the traditional approach of time series analysis, which may lead to biased conclusions. Some use traditional cointegration methods (e.g., E-G two-step method, J-J Test based on VAR multiple variables, etc.), which may give low reliability and have a weak statistical relationship in a situation where a small number of samples are examined. In light of these problems, the present study differs from previous ones by employing the ARDL model and bounds test that is more robust to the study on the relationship between housing prices and inflation.

Also, the inconsistent findings from the existing literature in the Chinese housing market are due to unreliable data. The Chinese HPI data used in previous research were estimated and released by the National Bureau of Statistics of China (NBSC). The two official HPIs are the Average Selling Price of New Residential Units (the Average Price Index) and the real estate price indices of 70 large- and medium-size cities (70-City Index). Unfortunately, both indices are widely criticized for two reasons. First, these two indicators, though published by the same government agency, conflict with each other (Ahuja, Cheung, Han, Porter, \& Zhang, 2010). Second, as shown in Wu, Gyourko, and Joseph (2016), these indices tend to underestimate the magnitude of the market growth. According to $\mathrm{Wu}$ et al. (2016), the Average Price Index is calculated without quality adjustment, and the "70-City Index" employs an over-simplified form of the matching approach. Both have some problems with methodologies.

To overcome the deficiency of the weighted average formula of "Average Price Index" and "70-City Index", Fang, Gu, Xiong, and Zhou (2016) proposed a hybrid

\footnotetext{
5 A referee commented that the research on the connection between housing prices and inflation is not limited to the residential real estate sector. Some studies have examined the relationship of inflation to commercial, retail and industrial property (for example, Barber, Robertson, \& Donald, 1997; Huang \& Hudson-Wilson, 2007; Leung, 2010).
} 
method of constructing HPIs for 120 major cities in China over the period 2003-2013. This method takes advantage of the strengths of two standard methods, namely, hedonic regression method and the repeat-sales method. Furthermore, it takes into account some key characteristics of the Chinese real estate market. Firstly, there are a large number of new home sales in the form of apartments. Secondly, they are frequently sold in a sequential manner in the same housing developments. Finally, they might share similar unobserved amenities as they are in the same housing developments. Based on these features, the hybrid approach employs a pseudo-repeat sales method by using pair sale prices at an individual development level rather than at an individual house level. In so doing, it can avoid the loss of information that might occur if the hedonic approach alone is used. At the same time, the hybrid approach ensures a representative sample by encompassing a large number of new home sales.

Based on the HPIs of 29 first-tier and second-tier cities constructed by Fang et al. (2016), this paper is the first attempt to use these newly built indices to examine the relationship between housing prices and inflation. Furthermore, most of the previous studies on Chinese HPIs are mainly focused on the whole country while they give less attention to the sharp variation of real estate markets at the regional levels. The works by Kuang and Liu (2015), Wu and Tidwell (2015), and Yu and Huang (2016) examined 35 Chinese cities to reveal the relationship between housing prices and inflation. Nevertheless, these studies have limitations of using HPI data published by the NBSC and the methods they adopt are less robust than the ARDL method.

To fill this gap, this paper attempts to re-analyze the relationship of Chinese housing prices and inflation, using, for the first time, new housing price indices of 29 first-tier and second-tier Chinese cities constructed by Fang et al. (2016), and employing the ARDL model and bounds test. The empirical results indicate that there is no long-run cointegration relationship between the HPI and CPI of 28 cities out of the 29 at a significant level of 5\%, and there is no long-run co-integration between the HPI and CPI of the remaining cities at a significant level of $2.5 \%$. These results lead to the conclusion that there is no long-run cointegration relationship between housing prices and inflation. Besides, we find that while the housing price indices of 29 cities increase rapidly, the consumer price indices grow relatively slowly. Therefore, the cumulative growth rate of HPI well outpaces that of CPI.

The remainder of the paper is organized as follows: Section 1 reviews the theoretical framework, followed by a discussion of the econometric model of the study in Section 2. Section 3 addresses the data and empirical analysis while Section 4 presents further robustness check. The last section concludes the paper.

\section{Theoretical framework}

This section presents a theoretical framework on the relationship between housing prices and inflation. According to Anari and Kolari (2002), housing expenditure is mainly characterized by its investment and consumption. Inflation can raise the construction costs of new houses with higher building material costs and with higher payments made to construction workers. The rise of construction costs of new houses will be transmitted to house prices, thus increasing the price of new houses. Since existing houses are substitutes for new ones, the higher the price of new houses, the higher the cost of replacing existing houses will be. Thus, existing house prices will increase accordingly.

There must be a certain relationship between house prices and service prices (i.e., net rent). In the competitive market, house prices should be equal to the value of future expected net rents (gross rental income minus operating expenses such as maintenance costs). If there are no taxes on incomes and capital gains, the present value model for the stream of expected rents can be specified as:

$$
H P=P V=\sum_{k=1}^{n} \frac{E_{t}\left(R_{t+k}\right)}{(1+r)^{k}},
$$

where: $P V$ means the present value of house price (equivalent to house price or HP); $n$ is the lifespan of the house; $E_{t}\left(R_{t+k}\right)$ denotes the annual net rent in period $t+k$, that is expected in period $t$, and $r$ is the discount rate. Net annual rent is the gross rent minus maintenance expenses. The accumulated depreciation charges at the end of the lifespan of the house amount to the present value. As the Property Law of the People's Republic of China stipulates that the land of the residential real estate shall be automatically renewed upon expiration, the flow of net rent is assumed to be permanent (i.e., $n=\infty$ ) in this paper. If rent and discount rates are constant, assuming the annual rent is a constant, Equation (1) can be rewritten as:

$$
H P=P V=\frac{R}{r} \text {. }
$$

According to Fisher's (1930) theory of a long-run relationship between real interest rates and nominal interest rates, real estate investors (or property owners) must consider the real level of rents to maintain and increase the value of their properties. This will inevitably link the rent to the inflation of non-housing goods and take into consideration the expected inflation in determining the rent. A natural way to estimate inflation is to use growth rates of consumer price indices (Arnold \& Auer, 2015).

Therefore, Equation (2) can be developed into:

$$
H P_{t}=P V_{t}=\frac{R\left(\frac{E_{t}\left(C P I_{t+1}\right)}{C P I_{b}}\right)}{r},
$$

where: $E_{t}\left(C P I_{t+1}\right)$ is the consumer price index value of a known period $t$, and the expected value of the period $t$ $+1, C P I_{b}$ is the base value of the consumer price index.

Assume that $\mathrm{R}$ and $\mathrm{r}$ are constants and $\mathrm{CPI}_{\mathrm{b}}=1$, taking the logarithms of both sides of Equation (3), we obtain:

$$
\operatorname{LOG}\left(H P_{t}\right)=C+\theta \cdot \operatorname{LOG}\left(E_{t}\left(C P I_{t+1}\right)\right) \text {, }
$$


where: $\theta=1$; constant $C=\operatorname{LOG}(R)-\operatorname{LOG}(r)$. Equation (4) is consistent with the so-called "Fisher effect" in the absence of taxes, and house prices are expected to change as consumer price elasticity (i.e., inflation) changes. Namely, house price and inflation have a certain relationship theoretically.

Following Bodie (1976) and Arnold and Auer (2015), when the long-run relationship Equation (4) exists, if $\theta \geq 0$, housing prices can hedge against inflation; if $\theta \geq 1$, this can be called a perfect hedge because the increase of housing prices can fully offset the price rise; if $0<\theta<1$, this indicates a stable positive relationship, which can be called an effective hedge.

\section{Econometric model}

The theoretical analysis in the previous section indicates that if we want to determine whether house price can hedge against inflation and the magnitude of the hedging, we need to first test the existence of the long-run relationship between house price and inflation. If there is evidence of a long-run relationship between the two variables, we can estimate $\theta$ to determine the magnitude of hedging.

Following Pesaran and Shin (1999), the ARDL model is employed to examine the relationship between housing prices and consumer prices in the long run. It is a co-integration method for simultaneously identifying the long and short-term relationships between time series variables.

There are three advantages to using this dynamic model. First, the ARDL test can overcome the limitation of non-stationary variables because it does not require variables to have the same order of integration. No matter if data are I (1) or I (0), or a mixture of I (0) and I (1), they can be included in the co-integration test, while all other methods require that the variables in a time-series regression are integrated of order one, i.e., the variables are I (1). Second, endogeneity problems can be avoided because some of the independent variables in the ARDL model are assumed to be endogenous. Third, the ARDL model performs well in small samples. In contrast, the traditional co-integration method (E-G two-step method, etc.) may have problems with small samples, and the conclusion may not be reliable.

Equation (4) is the static model, which does not explain the dynamic feature of the relationship between HPI and CPI. According to the previous economic theory of Equation (4), an ARDL representation of Equation (5) is established below:

$$
H P I_{t}=\alpha+\sum_{i=1}^{p} \gamma_{i} H P I_{t-i}+\sum_{i=0}^{q} \beta_{i} C P I_{t-i}+u_{t},
$$

where: $\alpha$ is the intercept; $\gamma_{i}$ and $\beta_{i}$ are the parameters of independent variables; $p$ is the lag of HPI; $q$ is the lag of $C P I ; u_{t}$ is the error term.
Equation (5) is estimated mainly through identifying the optimal numbers of lags by the AIC criterion or the SC criterion, and then tests the equation.

Equation (5) can be reformulated as Equation (6):

$$
\begin{aligned}
& \Delta H P I_{t}=\alpha+\delta_{1} H P I_{t-1}+\delta_{2} C P I_{t-1}+ \\
& \sum_{i=1}^{p-1} \gamma_{i}^{*} \Delta H P I_{t-i}+\sum_{i=0}^{q_{j}-1} \beta_{i}^{*} \Delta C P I_{t-i}+u_{t},
\end{aligned}
$$

where: $\alpha$ is the intercept; $-\delta_{2} / \delta_{1}$ is the long-run multiplier, and $\gamma_{i}^{*}$ and $\beta_{i}^{*}$ are short-term dynamic coefficients.

Based on Equation (6), this paper uses the bounds test (Pesaran \& Shin, 1999) to test the long-run relationship between HPI and CPI. We test whether the long-run relationship coefficients $\delta_{1}$ and $\delta_{2}$ are significantly different from 0 .

The null hypothesis is that no long-term effect exists, namely, $H_{0}: \delta_{1}=\delta_{2}=0$;

The alternative hypothesis is that a long-term effect exists, namely, $H_{1}: \delta_{1} \neq 0$,or $\delta_{2} \neq 0$;

The bounds test is used to calculate an F-statistic to determine whether there is a significant coefficient between HPI and CPI, thus showing whether there is a long-run relationship between them. The F-statistic used for the test is calculated by Equation (6) and is compared with the corresponding critical values given by Pesaran, Shin, and Smith (2001). If the F-statistic is less than the critical value, the null hypothesis can be accepted. That is, there is no long-run effect. On the contrary, if the F-statistic is greater than the critical value, the null hypothesis can be rejected.

If there is a long-run relationship between HPI and CPI, we need to find out its long-term influence coefficient. The long-term impact of CPI on HPI can be calculated by Equation (7):

$$
\theta=\frac{\sum_{i=0}^{q_{j}} \hat{\beta}_{i}}{\left(1-\sum_{i=1}^{p} \hat{\gamma}_{i}\right)} \text {. }
$$

If the long-term effect is estimated, the short-term effect can also be calculated by inferring the coefficient of different variables. By a simple formula conversion of Equation (5), the ARDL model can generate a dynamic error correction model (ECM) to help test the short-term relationship between HPI and CPI by introducing the error correction term $\mathrm{ECM}_{\mathrm{t}-1}$ and the error correction coefficient $\lambda$, which is shown in Equation (8):

$$
\begin{gathered}
\Delta H P I_{t}=\alpha_{0}+\sum_{i=1}^{p} \gamma_{i}^{*} \Delta H P I_{t-i}+ \\
\sum_{i=0}^{q_{j}} \beta_{i}^{*} \Delta C P I_{t-i}-\lambda E C M_{t-1}+\mu_{t .}
\end{gathered}
$$

Using the ARDL error correction model, the shortterm relationship can be analyzed for variables with the long-term relationship. 


\section{Empirical results}

\subsection{Data}

The variables in the present study comprise housing prices and inflation. The former is represented by the housing price index (HPI) and the latter the consumer price index (CPI). Data of the CPI are retrieved from the NBSC. The $\mathrm{CPI}$ in China does not include real estate prices, which has been specified in the Chinese CPI by the NBSC. HPI constructed by Fang et al. (2016), instead of the HPI issued by NBSC, is utilized. As presented above, the indices provided by the NBSC do not exactly reflect the changes in housing prices in local cities, while indices built by Fang et al. (2016) can more accurately measure the price level of residential real estate in local cities (see Fang et al. (2016) for detail). Both the CPI and HPI indices used in this paper span from January of 2003 to March of 2013, covering 11 years and 123 data points.

The real estate market has important local features. To ascertain an accurate analysis, representative cities in China are embraced rather than the whole country. Among the HPI indices for 120 cities constructed by Fang et al. (2016), we only chose those for 29 cities. Firstly, of the 120 cities, only 35 have the corresponding CPI data from the NBSC. When we further sort out the HPI data for these cities, we find five cities which lack complete data on HPI and one city's (Qingdao) second-order CPI sequence data are stationary and thereby this city is excluded for not meeting the data requirement for the follow-up model. In the end, there are 29 cities with relatively complete HPI and CPI data. They are first-tier and second-tier cities in China including some major cities such as Beijing, Tianjin, Shanghai, Nanjing, Guangzhou, Chongqing, Chengdu, Xian, Xiamen, Shenzhen, and Hangzhou. The scale of real estate development in these cities constitutes a large proportion of the whole country. Specifically, in 2013, the residential real estate sales area of the 29 cities comprised $29.97 \%$ of the country, and the number of sales accounted for $52.14 \% .{ }^{6}$ Obviously, these cities can be taken as representative of China as a whole.

\subsection{Analysis of the inflation-hedging ability of housing prices}

Over the past two decades, China's real estate market has developed dramatically, and inflation has grown modestly. The summary statistics of the overall HPI and CPI of the 29 cities are presented in Table 1 and Figure 2. The monthly cumulative growth rate of CPI was $132.96 \%$ during the
2003-2013 period, while the HPI change was 409.40\%. The standard deviations clearly show that HPI changes are significantly greater than the CPI change.

To further illustrate the relationship between HPI and CPI, we have selected four out of the 29 cities including Beijing, Shanghai, Chengdu, and Shenyang for analysis. Beijing and Shanghai represent the northern and southern first-tier cities respectively, while Shenyang and Chengdu represent the northern and southern second-tier cities. As can be seen from the trend line charts in Figure 3-6, both the HPI and CPI show an increasing trend. During the sample period, the overall HPI cumulative growth rate in all these cities surpasses the CPI cumulative growth rate by a great margin. However, the extent to which the aggregate growth rate of HPI exceeds that of CPI varies among the cities. For example, among the first tier cities, the monthly cumulative growth rate of HPI in Beijing is $759.962 \%$, and the average HPI growth rate is $1.676 \%$, while its monthly cumulative growth rate of CPI is $125.221 \%$ and its average CPI growth rate is $0.185 \%$. However, the cumulative growth rate of HPI in second-tier cities is less than that in first-tier cities. For example, in Shenyang, the accumulated growth of HPI is 3.13 times that of CPI, while in Beijing, the accumulated growth of HPI is 6.04 times that of CPI. Despite the variation, the HPI growth rate is generally higher than that of CPI in all the 29 cities as shown in Table 1.

The higher accumulative growth of HPI than that of CPI, and the fluctuations of HPI and CPI lines cannot indicate that HPI and CPI change synchronously (a hedging relationship), although they both have exhibited a long-term growth trend. The fluctuating relationship between HPI and $\mathrm{CPI}$ needs to be determined through further analysis.

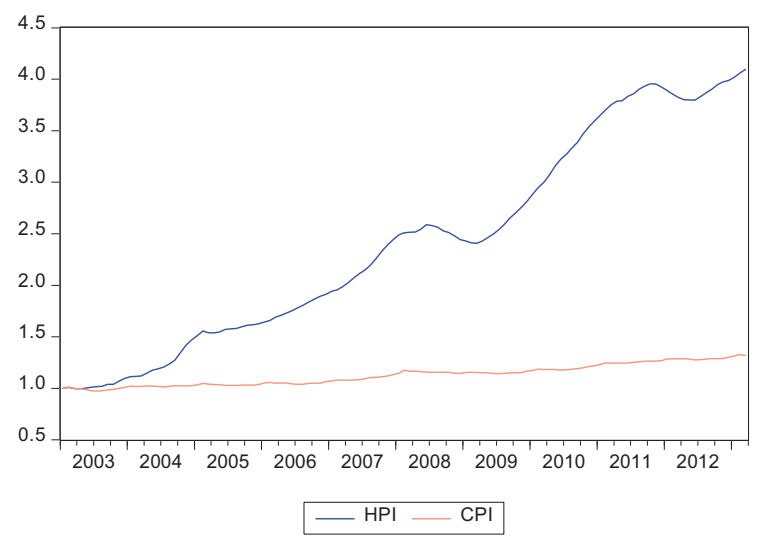

Figure 2. Overall HPI and CPI time plots of 29 cities

Table 1. Summary statistics of the overall HPI and CPI of 29 cities

\begin{tabular}{|c|c|c|c|c|c|}
\hline $\begin{array}{c}\text { Descriptive } \\
\text { variables }\end{array}$ & Mean & Median & Maximum & Minimum & Std. Dev. \\
\hline HPI & 2.4203 & 2.4303 & 4.0940 & 0.9951 & 1.0011 \\
\hline CPI & 1.1274 & 1.1434 & 1.3296 & 0.9719 & 0.1001 \\
\hline
\end{tabular}

\footnotetext{
6 The data come from the National Bureau of Statistics of China.
} 


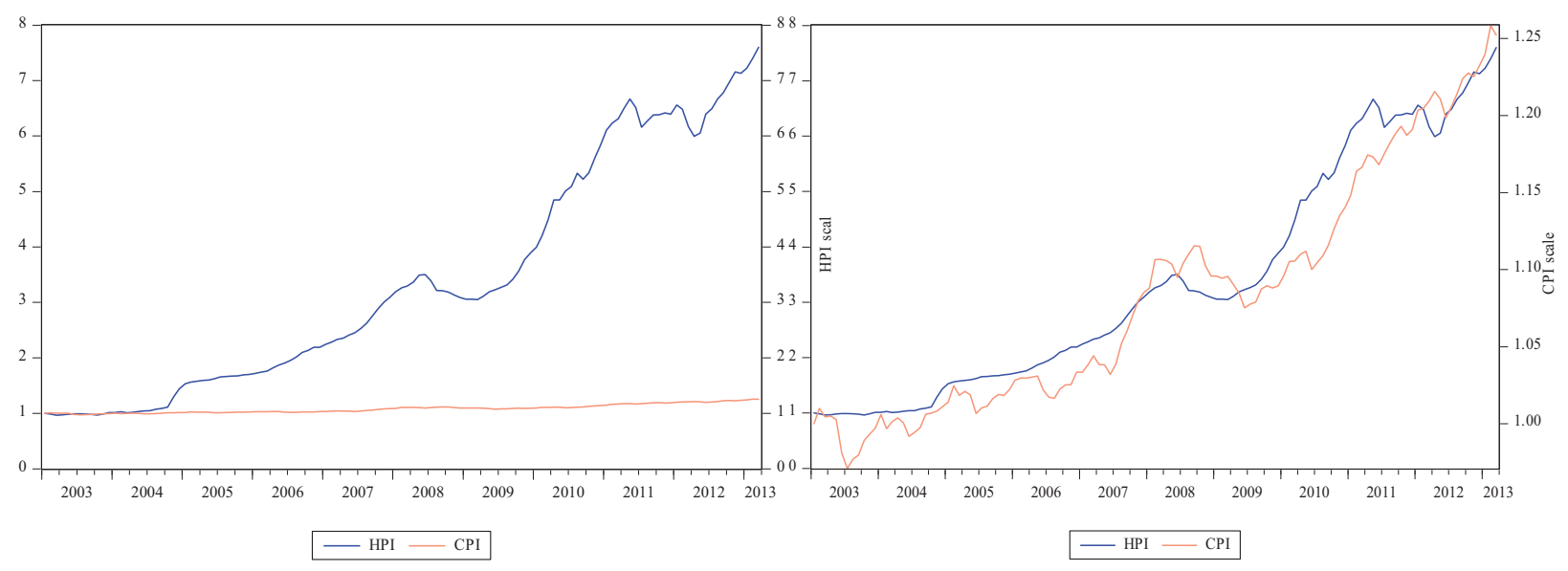

Figure 3. HPI and CPI time plots in Beijing

Note: In the above pictures, the left picture shows HPI and CPI on the same scale on the vertical axis. It can be seen from the figure that HPI rises much faster than CPI; the right one shows the fluctuation of HPI and CPI on different vertical axis scales. Clearly, HPI and CPI don't move synchronously.

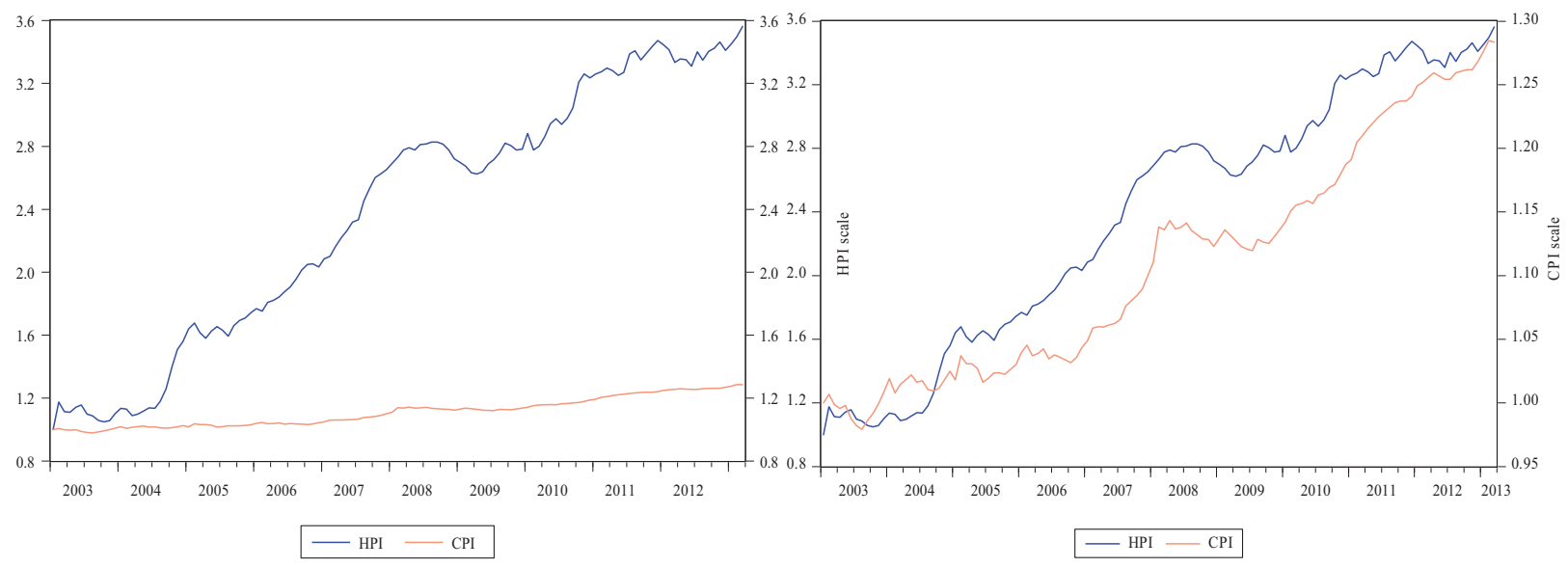

Figure 4. HPI and CPI time plots in Shanghai

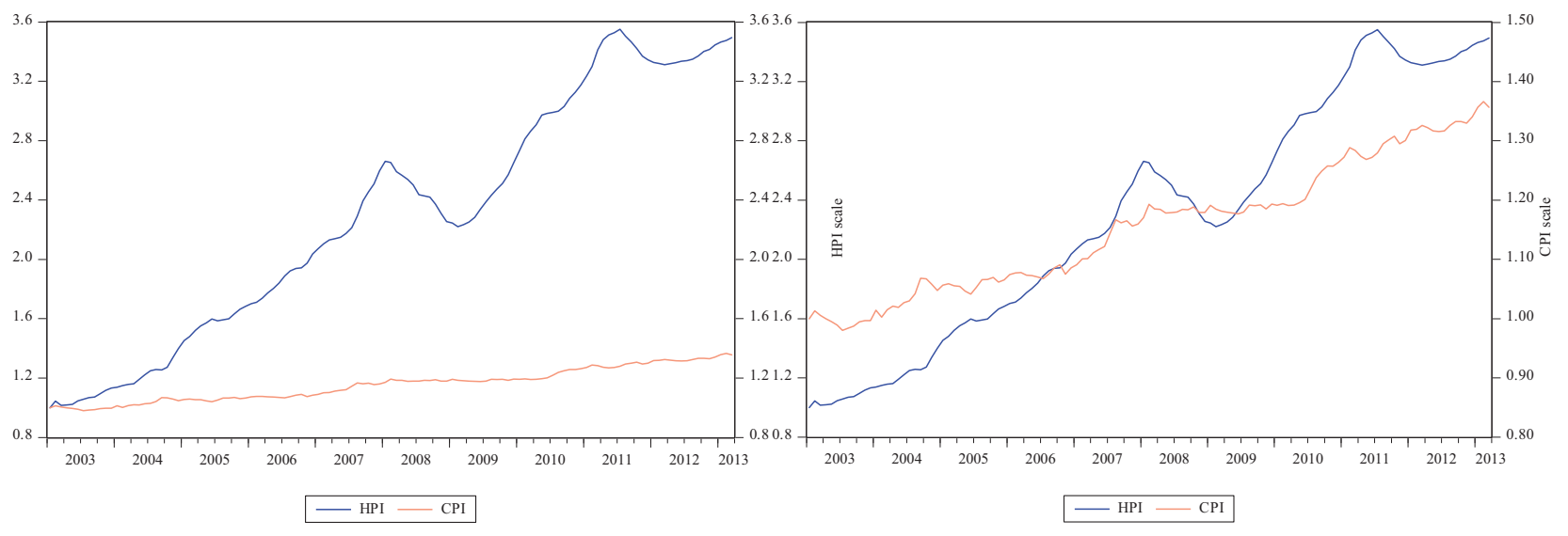

Figure 5. HPI and CPI time plots in Chengdu 


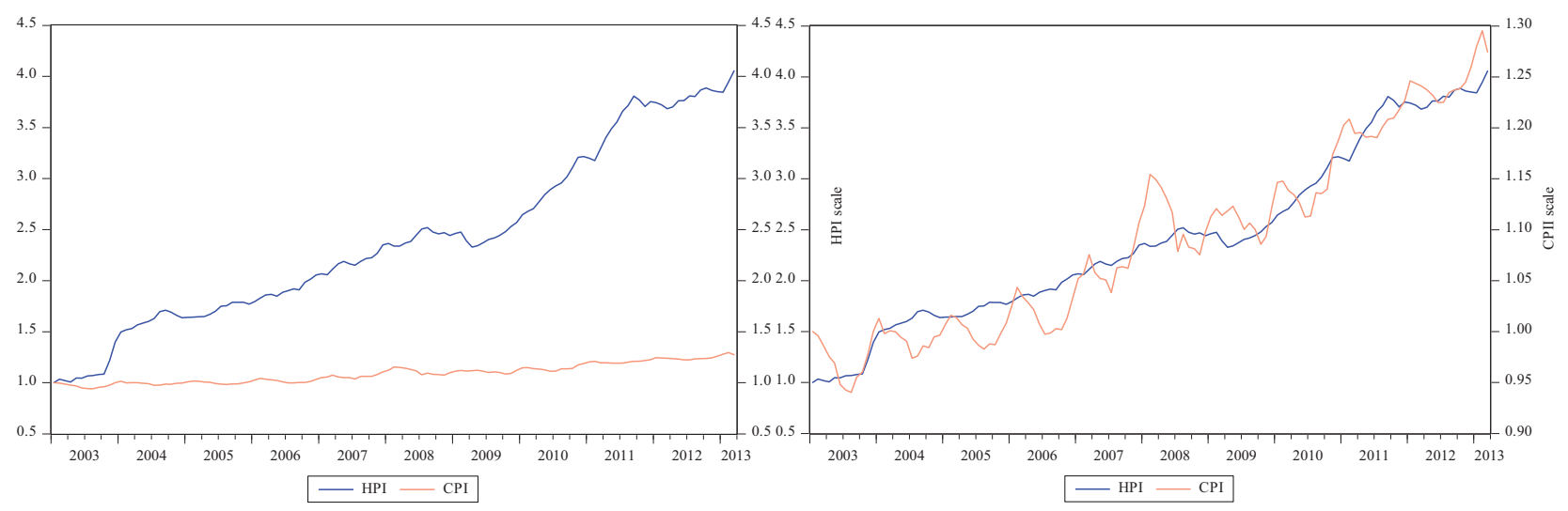

Figure 6. HPI and CPI time plots in Shenyang

Note: The trend line charts for CPI and HPI in other 25 cities are similar.

\subsection{Unit root tests for variables}

We need to make sure all variables are integrated of an order smaller than 2 to validate the ARDL methodology. To examine the level of integration in the data, we test for the presence of the unit root in them. Typically, a unit root test entails the Fisher-augmented Dickey-Fuller (ADF) tests, based on Equation (9).

$$
\Delta X_{t}=\alpha+\beta t+\delta X_{t-1}+\sum_{i=1}^{m} \beta_{i} \Delta X_{t-i}+\varepsilon_{t},
$$

where: $\varepsilon_{t}$ is the white noise error term, and $X$ is the logarithmic value of HPI or CPI respectively. According to the SC information criterion, the optimal lag period is selected automatically.

The null hypothesis is that the time series can be nonstationary and has a unit root, $H_{0}: \delta=0$;

The alternative hypothesis is that the time series can be stationary and has no unit root, $H_{1}: \delta<0$.

The results of the ADF test indicate the t-statistic values of LOG_CPI of 21 cities including Beijing, Shanghai, Changchun, etc. are greater than the critical values. Therefore, the null hypothesis is accepted, which indicates that the data of LOG_CPI have unit roots, and it is nonstationary in level.

Furthermore, the data of LOG_CPI of 21 cities are stationary at $5 \%$ level of significance in the first difference. In the other eight cities including Shenyang, Jinan, and Zhengzhou, the data of LOG_CPI are stationary at a 5\% level of significance in level. As to the result of the ADF test for HPI, the data of LOG_HPI from all 29 cities are non-stationary in level at a $5 \%$ level of significance, but all of the LOG_HPI become stationary after the first differencing.

After test for unit root in the first difference, both $\triangle$ LOG_HPI and $\Delta$ LOG_CPI pass the test of a unit root, and the null hypothesis is not accepted, so the data of $\triangle$ LOG_HPI and $\triangle$ LOG_CPI are stationary. That is, for some cities, LOG_CPI is I (0); for other cities, LOG_CPI is I (1). However, for all cities, LOG_HPI is I (1). None of the series are integrated of I (2). In other words, variables are stationary at the level or in the first difference. According to the basic conditions of the ARDL model, the sequence data in I (0) or I (1) is stationary so that ARDL co-integration analysis can be performed.

\subsection{ARDL model and bounds test}

To identify the relationship between housing prices and inflation, an ARDL model is formulated using the logarithm HPI and CPI data, and the specification of this model is as follows:

$$
\begin{aligned}
& L O G_{-} H P I_{t}=\alpha+\sum_{i=1}^{p} \gamma_{i} L O G_{-} H P I_{t-i}+ \\
& \sum_{i=0}^{q} \beta_{i} L O G_{-} C P I_{t-i}+u_{t} .
\end{aligned}
$$

The lag length of the model is determined by the Schwarz criterion, as it is a consistent model selector. After the lag length is selected, we use the Breusch-Godfrey serial correlation LM test to test whether the residuals are serially uncorrelated. ${ }^{7}$ HAC (Newey-West) is also adopted to adjust the possible heteroskedasticity (Table 2).

Subsequently, Equation (6) is converted into Equation (11), which can perform a long-term cointegration test of ARDL model, bounds test. The null hypothesis is that there is no long-term relationship between LOG_HPI and LOG_CPI, $\mathrm{H}_{0}: \delta_{1}=\delta_{2}=0$.

$$
\begin{aligned}
& \Delta L O G_{-} H P I_{t}=\alpha+\delta_{1} L O G_{-} H P I_{t-1}+\delta_{2} L O G_{-} C P I_{t-1}+ \\
& \sum_{i=1}^{p-1} \gamma_{i}^{*} \Delta L O G_{-} H P I_{t-i}+\sum_{i=0}^{q-1} \beta_{i}^{*} \Delta L O G_{-} C P I_{t-i}+\mu_{t} .
\end{aligned}
$$

\footnotetext{
7 The LM tests for all cities pass except for Shanghai, Harbin, and Shijiazhuang. For these three cities, we add one or two more lags for HPI in the estimation to make sure the residuals serially uncorrelated.
} 
Table 2. ARDL estimations

\begin{tabular}{|c|c|c|c|c|c|c|}
\hline No. & City & Variable & Coefficient & Std. Error & $\mathrm{t}$-statistic & Prob. \\
\hline \multirow[t]{5}{*}{1} & \multirow[t]{5}{*}{ Bejing } & LOG_HPI(-1) & 1.4905 & 0.0719 & 20.7209 & 0.0000 \\
\hline & & LOG_HPI(-2) & -0.5446 & 0.0766 & -7.1110 & 0.0000 \\
\hline & & LOG_CPI & -0.1673 & 0.0853 & -1.9617 & 0.0522 \\
\hline & & $\bar{C}$ & -0.0054 & 0.0050 & -1.0923 & 0.2769 \\
\hline & & @TREND & 0.0013 & 0.0005 & 2.8767 & 0.0048 \\
\hline \multirow[t]{7}{*}{2} & \multirow[t]{7}{*}{ Shanghai } & LOG_HPI $(-1)$ & 1.3646 & 0.1165 & 11.7094 & 0.0000 \\
\hline & & LOG_HPI(-2) & -0.4084 & 0.1188 & -3.4377 & 0.0008 \\
\hline & & LOG_HPI(-3) & 0.0138 & 0.0656 & 0.2095 & 0.8345 \\
\hline & & LOG_CPI & -0.0976 & 0.2875 & -0.3397 & 0.7347 \\
\hline & & LOG_CPI(-1) & -0.0794 & 0.2907 & -0.2731 & 0.7853 \\
\hline & & $\mathrm{C}$ & 0.0081 & 0.0071 & 1.1408 & 0.2563 \\
\hline & & @TREND & 0.0006 & 0.0003 & 2.0461 & 0.0431 \\
\hline \multirow[t]{5}{*}{3} & \multirow[t]{5}{*}{ Guangzhou } & LOG_HPI(-1) & 1.5603 & 0.1005 & 15.5300 & 0.0000 \\
\hline & & LOG_HPI(-2) & -0.6164 & 0.0900 & -6.8494 & 0.0000 \\
\hline & & LOG_CPI & -0.0109 & 0.1136 & -0.0960 & 0.9237 \\
\hline & & $\mathrm{C}$ & 0.0056 & 0.0065 & 0.8553 & 0.3941 \\
\hline & & @TREND & 0.0008 & 0.0003 & 2.3430 & 0.0208 \\
\hline \multirow[t]{6}{*}{4} & \multirow[t]{6}{*}{ Shenzhen } & LOG_HPI(-1) & 1.5606 & 0.1036 & 15.0598 & 0.0000 \\
\hline & & LOG_HPI(-2) & -0.5899 & 0.1013 & -5.8204 & 0.0000 \\
\hline & & LOG_CPI & 0.1236 & 0.3063 & 0.4036 & 0.6873 \\
\hline & & LOG_CPI(-1) & -0.4755 & 0.2747 & -1.7311 & 0.0861 \\
\hline & & $\mathrm{C}$ & -0.0108 & 0.0062 & -1.7440 & 0.0838 \\
\hline & & @TREND & 0.0012 & 0.0003 & 3.4932 & 0.0007 \\
\hline \multirow[t]{5}{*}{5} & \multirow[t]{5}{*}{ Changchun } & LOG_HPI(-1) & 1.3900 & 0.0915 & 15.1858 & 0.0000 \\
\hline & & LOG_HPI(-2) & -0.4308 & 0.0944 & -4.5629 & 0.0000 \\
\hline & & LOG_CPI & -0.0835 & 0.1787 & -0.4675 & 0.6410 \\
\hline & & $\mathrm{C}$ & 0.0162 & 0.0154 & 1.0481 & 0.2968 \\
\hline & & @TREND & 0.0007 & 0.0003 & 2.4302 & 0.0166 \\
\hline \multirow[t]{5}{*}{6} & \multirow[t]{5}{*}{ Changsha } & LOG_HPI(-1) & 1.4774 & 0.0804 & 18.3773 & 0.0000 \\
\hline & & LOG_HPI(-2) & -0.5595 & 0.1099 & -5.0929 & 0.0000 \\
\hline & & LOG_CPI & 0.0207 & 0.1434 & 0.1445 & 0.8854 \\
\hline & & $\mathrm{C}$ & 0.0030 & 0.0075 & 0.3965 & 0.6925 \\
\hline & & @TREND & 0.0009 & 0.0005 & 1.8176 & 0.0717 \\
\hline \multirow[t]{5}{*}{7} & \multirow[t]{5}{*}{ Chengdu } & LOG_HPI $(-1)$ & 1.6089 & 0.1203 & 13.3762 & 0.0000 \\
\hline & & LOG_HPI(-2) & -0.6208 & 0.1257 & -4.9407 & 0.0000 \\
\hline & & LOG_CPI & -0.1063 & 0.1144 & -0.9289 & 0.3549 \\
\hline & & $\mathrm{C}$ & 0.0042 & 0.0036 & 1.1645 & 0.2466 \\
\hline & & @TREND & 0.0004 & 0.0003 & 1.2339 & 0.2197 \\
\hline \multirow[t]{5}{*}{8} & \multirow[t]{5}{*}{ Chongqing } & LOG_HPI(-1) & 1.5897 & 0.0577 & 27.5295 & 0.0000 \\
\hline & & LOG_HPI(-2) & -0.6403 & 0.0535 & -11.9654 & 0.0000 \\
\hline & & LOG_CPI & 0.0707 & 0.1147 & 0.6164 & 0.5388 \\
\hline & & $\mathrm{C}$ & 0.0097 & 0.0071 & 1.3579 & 0.1771 \\
\hline & & @TREND & 0.0005 & 0.0002 & 2.2471 & 0.0265 \\
\hline \multirow[t]{5}{*}{9} & Dalian & LOG_HPI(-1) & 1.3856 & 0.0917 & 15.1175 & 0.0000 \\
\hline & & LOG_HPI(-2) & -0.4291 & 0.0985 & -4.3571 & 0.0000 \\
\hline & & LOG_CPI & -0.1527 & 0.1251 & -1.2210 & 0.2246 \\
\hline & & $\mathrm{C}$ & 0.0150 & 0.0131 & 1.1426 & 0.2556 \\
\hline & & @TREND & 0.0008 & 0.0003 & 2.7072 & 0.0078 \\
\hline 10 & Fuzhou & LOG_HPI(-1) & 1.5518 & 0.0762 & 20.3639 & 0.0000 \\
\hline & & LOG_HPI(-2) & -0.5723 & 0.0788 & -7.2644 & 0.0000 \\
\hline & & LOG_CPI & 0.0437 & 0.1369 & 0.3188 & 0.7504 \\
\hline & & $\mathrm{C}$ & 0.0065 & 0.0048 & 1.3388 & 0.1833 \\
\hline & & @TREND & 0.0001 & 0.0003 & 0.4084 & 0.6838 \\
\hline 11 & Haikou & LOG_HPI(-1) & 0.9473 & 0.0331 & 28.6192 & 0.0000 \\
\hline & & LOG_CPI & -0.0084 & 0.1562 & -0.0535 & 0.9574 \\
\hline & & $\mathrm{C}$ & 0.0024 & 0.0084 & 0.2842 & 0.7768 \\
\hline & & @TREND & 0.0006 & 0.0004 & 1.6968 & 0.0924 \\
\hline
\end{tabular}


Continued Table 2

\begin{tabular}{|c|c|c|c|c|c|c|}
\hline No. & City & Variable & Coefficient & Std. Error & t-statistic & Prob. \\
\hline \multirow[t]{9}{*}{12} & \multirow[t]{9}{*}{ Hangzhou } & LOG_HPI(-1) & 1.3636 & 0.0818 & 16.6600 & 0.0000 \\
\hline & & LOG_HPI(-2) & -0.4115 & 0.0830 & -4.9583 & 0.0000 \\
\hline & & LOG_CPI & -0.0845 & 0.2665 & -0.3171 & 0.7518 \\
\hline & & LOG_CPI $(-1)$ & 0.7054 & 0.4030 & 1.7502 & 0.0829 \\
\hline & & LOG_CPI(-2) & -0.6714 & 0.2366 & -2.8377 & 0.0054 \\
\hline & & LOG_CPI(-3) & 0.8844 & 0.3274 & 2.7016 & 0.0080 \\
\hline & & LOG_CPI $(-4)$ & -1.0537 & 0.2945 & -3.5785 & 0.0005 \\
\hline & & $\mathrm{C}$ & -0.0022 & 0.0059 & -0.3803 & 0.7044 \\
\hline & & @TREND & 0.0009 & 0.0004 & 2.4884 & 0.0143 \\
\hline \multirow[t]{10}{*}{13} & \multirow[t]{10}{*}{ Hefei } & LOG_HPI(-1) & 1.5890 & 0.1023 & 15.5304 & 0.0000 \\
\hline & & LOG_HPI(-2) & -0.6111 & 0.1513 & -4.0386 & 0.0001 \\
\hline & & LOG_HPI(-3) & -0.1339 & 0.1672 & -0.8010 & 0.4249 \\
\hline & & LOG_HPI(-4) & 0.4413 & 0.2811 & 1.5700 & 0.1194 \\
\hline & & LOG_HPI(-5) & -0.7242 & 0.2250 & -3.2194 & 0.0017 \\
\hline & & LOG_HPI(-6) & 0.6179 & 0.2637 & 2.3435 & 0.0210 \\
\hline & & LOG_HPI(-7) & -0.2277 & 0.1452 & -1.5679 & 0.1199 \\
\hline & & LOG_CPI & -0.0435 & 0.0682 & -0.6381 & 0.5248 \\
\hline & & $\mathrm{C}$ & 0.0042 & 0.0041 & 1.0314 & 0.3047 \\
\hline & & @TREND & 0.0006 & 0.0004 & 1.5965 & 0.1133 \\
\hline \multirow[t]{7}{*}{14} & \multirow[t]{7}{*}{ Harbin } & LOG_HPI(-1) & 1.0924 & 0.1168 & 9.3562 & 0.0000 \\
\hline & & LOG_HPI(-2) & -0.3943 & 0.1448 & -2.7231 & 0.0075 \\
\hline & & LOG_HPI(-3) & 0.1813 & 0.1220 & 1.4863 & 0.1400 \\
\hline & & LOG_CPI & -0.0006 & 0.3549 & -0.0017 & 0.9986 \\
\hline & & LOG_CPI $(-1)$ & -0.1359 & 0.3822 & -0.3554 & 0.7229 \\
\hline & & $\mathrm{C}$ & 0.0093 & 0.0127 & 0.7319 & 0.4657 \\
\hline & & @TREND & 0.0016 & 0.0007 & 2.1017 & 0.0378 \\
\hline \multirow[t]{5}{*}{15} & \multirow[t]{5}{*}{ Hohhot } & LOG_HPI(-1) & 1.2782 & 0.1012 & 12.6345 & 0.0000 \\
\hline & & LOG_HPI(-2) & -0.3301 & 0.1197 & -2.7575 & 0.0068 \\
\hline & & LOG_CPI & -0.1677 & 0.0951 & -1.7630 & 0.0805 \\
\hline & & $\mathrm{C}$ & -0.0029 & 0.0057 & -0.5003 & 0.6178 \\
\hline & & @TREND & 0.0010 & 0.0004 & 2.3777 & 0.0191 \\
\hline \multirow[t]{8}{*}{16} & \multirow[t]{8}{*}{ Jinan } & LOG_HPI(-1) & 1.1837 & 0.0940 & 12.5920 & 0.0000 \\
\hline & & LOG_HPI(-2) & -0.2579 & 0.0904 & -2.8521 & 0.0052 \\
\hline & & LOG_CPI & 0.8339 & 0.7992 & 1.0434 & 0.2990 \\
\hline & & LOG_CPI $(-1)$ & -1.9586 & 1.4996 & -1.3061 & 0.1942 \\
\hline & & LOG_CPI $(-2)$ & 2.5706 & 1.4966 & 1.7176 & 0.0886 \\
\hline & & LOG_CPI $(-3)$ & -1.7563 & 0.7605 & -2.3094 & 0.0228 \\
\hline & & $\mathrm{C}$ & 0.0198 & 0.0136 & 1.4540 & 0.1488 \\
\hline & & @TREND & 0.0013 & 0.0007 & 1.8942 & 0.0608 \\
\hline \multirow[t]{5}{*}{17} & \multirow[t]{5}{*}{ Kunming } & LOG_HPI(-1) & 1.2131 & 0.1218 & 9.9584 & 0.0000 \\
\hline & & LOG_HPI(-2) & -0.2933 & 0.1254 & -2.3386 & 0.0211 \\
\hline & & LOG_CPI & 0.0818 & 0.1897 & 0.4313 & 0.6671 \\
\hline & & $\mathrm{C}$ & 0.0175 & 0.0090 & 1.9421 & 0.0545 \\
\hline & & @TREND & 0.0005 & 0.0005 & 0.9506 & 0.3438 \\
\hline \multirow[t]{5}{*}{18} & \multirow[t]{5}{*}{ Nanchang } & LOG_HPI(-1) & 1.1721 & 0.1455 & 8.0575 & 0.0000 \\
\hline & & LOG_HPI(-2) & -0.2679 & 0.1166 & -2.2980 & 0.0234 \\
\hline & & LOG_CPI & -0.1217 & 0.1702 & -0.7151 & 0.4760 \\
\hline & & $\mathrm{C}$ & -0.0026 & 0.0077 & -0.3433 & 0.7320 \\
\hline & & @TREND & 0.0014 & 0.0007 & 2.0647 & 0.0412 \\
\hline \multirow[t]{5}{*}{19} & \multirow[t]{5}{*}{ Nanjing } & LOG_HPI(-1) & 1.4365 & 0.0886 & 16.2054 & 0.0000 \\
\hline & & LOG_HPI(-2) & -0.4669 & 0.0988 & -4.7245 & 0.0000 \\
\hline & & LOG_CPI & -0.1758 & 0.1645 & -1.0684 & 0.2875 \\
\hline & & $\mathrm{C}$ & 0.0124 & 0.0132 & 0.9394 & 0.3495 \\
\hline & & @TREND & 0.0009 & 0.0003 & 3.0145 & 0.0032 \\
\hline 20 & Nanning & LOG_HPI(-1) & 1.3543 & 0.0932 & 14.5327 & 0.0000 \\
\hline & & LOG_HPI(-2) & -0.5424 & 0.1572 & -3.4502 & 0.0008 \\
\hline & & LOG_HPI(-3) & -0.0807 & 0.1391 & -0.5800 & 0.5631 \\
\hline & & LOG_HPI(-4) & 0.4863 & 0.1254 & 3.8793 & 0.0002 \\
\hline & & LOG_HPI(-5) & -0.2334 & 0.0820 & -2.8463 & 0.0053 \\
\hline
\end{tabular}


End of Table 2

\begin{tabular}{|c|c|c|c|c|c|c|}
\hline No. & City & Variable & Coefficient & Std. Error & t-statistic & Prob. \\
\hline & & LOG_CPI & 0.0075 & 0.0770 & 0.0969 & 0.9230 \\
\hline & & $\mathrm{C}$ & 0.0137 & 0.0054 & 2.5276 & 0.0129 \\
\hline & & @TREND & 0.0001 & 0.0004 & 0.2239 & 0.8233 \\
\hline \multirow[t]{6}{*}{21} & \multirow[t]{6}{*}{ Ningbo } & LOG_HPI(-1) & 1.4467 & 0.1847 & 7.8304 & 0.0000 \\
\hline & & LOG_HPI(-2) & -0.6328 & 0.3471 & -1.8232 & 0.0709 \\
\hline & & LOG_HPI(-3) & 0.1719 & 0.1559 & 1.1028 & 0.2724 \\
\hline & & LOG_CPI & -0.1445 & 0.1477 & -0.9783 & 0.3300 \\
\hline & & $\mathrm{C}$ & 0.0158 & 0.0101 & 1.5644 & 0.1205 \\
\hline & & @TREND & 0.0004 & 0.0005 & 0.8159 & 0.4163 \\
\hline \multirow{6}{*}{22} & \multirow[t]{6}{*}{ Shenyang } & LOG_HPI(-1) & 1.5307 & 0.0962 & 15.9046 & 0.0000 \\
\hline & & LOG_HPI(-2) & -0.7869 & 0.2027 & -3.8819 & 0.0002 \\
\hline & & LOG_HPI(-3) & 0.1853 & 0.0918 & 2.0192 & 0.0458 \\
\hline & & LOG_CPI & 0.0915 & 0.0778 & 1.1764 & 0.2419 \\
\hline & & $\mathrm{C}$ & 0.0299 & 0.0134 & 2.2224 & 0.0282 \\
\hline & & @TREND & 0.0004 & 0.0003 & 1.7222 & 0.0878 \\
\hline \multirow[t]{7}{*}{23} & \multirow{7}{*}{ Shijiazhuang } & LOG_HPI(-1) & 1.3656 & 0.1199 & 11.3910 & 0.0000 \\
\hline & & LOG_HPI(-2) & -0.4059 & 0.1224 & -3.3159 & 0.0012 \\
\hline & & LOG_HPI(-3) & 0.0154 & 0.0663 & 0.2330 & 0.8162 \\
\hline & & LOG_CPI & -0.0164 & 0.1456 & -0.1125 & 0.9107 \\
\hline & & LOG_CPI(-1) & -0.0988 & 0.1652 & -0.5979 & 0.5511 \\
\hline & & $\mathrm{C}$ & 0.0099 & 0.0072 & 1.3690 & 0.1737 \\
\hline & & @TREND & 0.0005 & 0.0003 & 1.8232 & 0.0709 \\
\hline \multirow[t]{5}{*}{24} & \multirow[t]{5}{*}{ Tianjin } & LOG_HPI(-1) & 1.4721 & 0.1230 & 11.9704 & 0.0000 \\
\hline & & LOG_HPI(-2) & -0.4971 & 0.1299 & -3.8279 & 0.0002 \\
\hline & & LOG_CPI & -0.2939 & 0.1003 & -2.9288 & 0.0041 \\
\hline & & $\mathrm{C}$ & 0.0034 & 0.0087 & 0.3898 & 0.6974 \\
\hline & & @TREND & 0.0009 & 0.0003 & 2.8352 & 0.0054 \\
\hline \multirow[t]{6}{*}{25} & \multirow[t]{6}{*}{ Urumqi } & LOG_HPI(-1) & 1.3863 & 0.0683 & 20.2936 & 0.0000 \\
\hline & & LOG_HPI(-2) & -0.6679 & 0.1236 & -5.4054 & 0.0000 \\
\hline & & LOG_HPI(-3) & 0.2251 & 0.0828 & 2.7195 & 0.0076 \\
\hline & & LOG_CPI & 0.0435 & 0.0696 & 0.6250 & 0.5332 \\
\hline & & $\mathrm{C}$ & 0.0027 & 0.0069 & 0.3903 & 0.6971 \\
\hline & & @TREND & 0.0007 & 0.0003 & 2.4533 & 0.0157 \\
\hline \multirow[t]{7}{*}{26} & \multirow[t]{7}{*}{ Xiamen } & LOG_HPI(-1) & 1.1537 & 0.1176 & 9.8106 & 0.0000 \\
\hline & & LOG_HPI(-2) & -0.1814 & 0.1173 & -1.5467 & 0.1247 \\
\hline & & LOG_CPI & 0.1279 & 0.3207 & 0.3987 & 0.6908 \\
\hline & & LOG_CPI $(-1)$ & 0.3457 & 0.4434 & 0.7797 & 0.4372 \\
\hline & & LOG_CPI(-2) & -0.9786 & 0.3275 & -2.9880 & 0.0034 \\
\hline & & $\mathrm{C}$ & 0.0008 & 0.0061 & 0.1355 & 0.8924 \\
\hline & & @TREND & 0.0012 & 0.0003 & 3.4146 & 0.0009 \\
\hline \multirow[t]{5}{*}{27} & \multirow[t]{5}{*}{ Xi'an } & LOG_HPI(-1) & 1.3729 & 0.0827 & 16.5986 & 0.0000 \\
\hline & & LOG_HPI(-2) & -0.4390 & 0.0981 & -4.4761 & 0.0000 \\
\hline & & LOG_CPI & -0.1056 & 0.0805 & -1.3125 & 0.1920 \\
\hline & & $\mathrm{C}$ & 0.0002 & 0.0054 & 0.0438 & 0.9651 \\
\hline & & @TREND & 0.0010 & 0.0005 & 1.8663 & 0.0645 \\
\hline \multirow[t]{5}{*}{28} & \multirow[t]{5}{*}{ Xining } & LOG_HPI(-1) & 1.1749 & 0.1001 & 11.7360 & 0.0000 \\
\hline & & LOG_HPI(-2) & -0.2280 & 0.1029 & -2.2162 & 0.0286 \\
\hline & & LOG_CPI & 0.0020 & 0.0930 & 0.0220 & 0.9825 \\
\hline & & $\mathrm{C}$ & -0.0148 & 0.0116 & -1.2731 & 0.2055 \\
\hline & & @TREND & 0.0008 & 0.0004 & 1.8641 & 0.0648 \\
\hline \multirow[t]{5}{*}{29} & \multirow[t]{5}{*}{ Zhengzhou } & LOG_HPI(-1) & 1.3275 & 0.0946 & 14.0361 & 0.0000 \\
\hline & & LOG_HPI(-2) & -0.4320 & 0.1022 & -4.2268 & 0.0000 \\
\hline & & LOG_CPI & 0.0619 & 0.1451 & 0.4262 & 0.6708 \\
\hline & & $\mathrm{C}$ & 0.0101 & 0.0060 & 1.6746 & 0.0967 \\
\hline & & @TREND & 0.0013 & 0.0006 & 2.1056 & 0.0374 \\
\hline
\end{tabular}

Note: The lag length of the model is determined by the Schwarz criterion and HAC (Newy-West) is used for adjusting the heteroskedasticity. 
For different cities, the F-statistic values in the bounds test of the ARDL model are estimated separately and are compared with the critical values (see Table 4 ) specified by Pesaran and Shin (1999) and Pesaran et al. (2001). If the calculated F-statistic is less than the critical value, the null hypothesis is accepted. If the calculated F-statistic exceeds the critical value, the null hypothesis can be rejected.

The bounds test results are shown in Table 3 . Table 4 presents the critical value where the lower bound if all variables are stationary and the upper bound applies when all of them are integrated of order 1. The F-statistic of most cities (28 cities) are below the critical value at the significance level of $5 \%$, and the null hypothesis that there is no long-term relationship between HPI and CPI in most cities is accepted. Meanwhile, the F-statistic of the city, Shenzhen, exceeds the critical value at the significance level of $5 \%$. Hence, the null hypothesis is rejected, suggesting that there is a connection between HPI and CPI. However, if the statistical significance level is at $2.5 \%$, the F-statistic values of all cities' ARDL models are less than the critical values, and the null hypothesis is accepted. Based on the above results, we can conclude that there is no long-run relationship between housing prices and inflation in the first-tier and second-tier cities in China in the sample period. According to the definition of inflation-hedging, our results indicate housing prices in China is not an effective hedge against inflation.

Table 3. Bounds tests of 29 cities when actual inflation is used

\begin{tabular}{|c|c|c|c|c|c|}
\hline No. & City & F-statistic & No. & City & F-statistic \\
\hline 1 & Beijing & 4.9703 & 16 & Jinan & 3.1755 \\
\hline 2 & Shanghai & 1.8876 & 17 & Kunming & 3.4515 \\
\hline 3 & Guangzhou & 4.3341 & 18 & Nanchang & 4.5841 \\
\hline 4 & Shenzhen & 7.5537 & 19 & Nanjing & 2.8034 \\
\hline 5 & Changchun & 2.5123 & 20 & Nanning & 0.1756 \\
\hline 6 & Changsha & 5.2034 & 21 & Ningbo & 0.4855 \\
\hline 7 & Chengdu & 2.0783 & 22 & Shenyang & 6.1625 \\
\hline 8 & Chongqing & 3.7862 & 23 & Shijiazhuang & 1.6031 \\
\hline 9 & Dalian & 3.0382 & 24 & Tianjin & 2.5472 \\
\hline 10 & Fuzhou & 0.7249 & 25 & Urumqi & 2.1105 \\
\hline 11 & Haikou & 1.7144 & 26 & Xiamen & 6.7324 \\
\hline 12 & Hangzhou & 4.7965 & 27 & Xian & 3.3871 \\
\hline 13 & Hefei & 3.1541 & 28 & Xining & 3.6833 \\
\hline 14 & Harbin & 3.8969 & 29 & Zhengzhou & 4.4468 \\
\hline 15 & Hohhot & 3.2800 & & & \\
\hline
\end{tabular}

Table 4. Bound at different significance levels

\begin{tabular}{|c|c|c|c|}
\hline \multicolumn{2}{|c|}{ Bound (Significance is 5\%) } & \multicolumn{2}{c|}{ Bound (Significance is 2.5\%) } \\
\hline I (0) Bound & I (1) Bound & I (0) Bound & I (1) Bound \\
\hline 6.56 & 7.30 & 7.46 & 8.27 \\
\hline
\end{tabular}

Note: The critical values are provided by Eviews 10.0 dynamic simulation.

\section{Robustness check}

In some existing studies (Christou et al., 2018; Kuang \& Liu, 2015 , etc.), actual inflation (AI) is used to test the relationship between housing prices and inflation. However, other studies (Bond \& Seiler, 1998; and Wu \& Tidwell, 2015) first decompose the actual inflation into expected and unexpected components and then examine the relationship of housing prices with expected inflation (EI) and unexpected inflation (UI) respectively. In this section, we follow the literature to divide actual inflation into expected and unexpected components and test their relationship with housing prices as a robustness check of our previous results.

Expected inflation (EI), due to the paucity of its data, is estimated based on actual inflation using an Autoregressive Integrated Moving Average (ARIMA) ${ }^{8}$ model (Gatzlaff,

Table 5. Bounds test of 29 cities when expected and unexpected inflations are used

\begin{tabular}{|c|c|c|c|}
\hline \multirow{2}{*}{ No. } & \multirow{2}{*}{ City } & \multicolumn{2}{|c|}{ F-statistic } \\
\hline & & HPI-EI & HPI-UI \\
\hline 1 & Bejing & 8.1699 & 5.2067 \\
\hline 2 & Shanghai & 1.4199 & 1.9349 \\
\hline 3 & Guangzhou & 5.9982 & 5.4198 \\
\hline 4 & Shenzhen & 7.2407 & 6.7576 \\
\hline 5 & Changchun & 6.3715 & 5.4550 \\
\hline 6 & Changsha & 6.7702 & 5.2074 \\
\hline 7 & Chengdu & 1.2408 & 3.9417 \\
\hline 8 & Chongqing & 3.4601 & 3.0739 \\
\hline 9 & Dalian & 2.3269 & 2.9655 \\
\hline 10 & Fuzhou & 0.6763 & 0.5834 \\
\hline 11 & Haikou & 7.0814 & 1.7749 \\
\hline 12 & Hangzhou & 4.1638 & 3.6342 \\
\hline 13 & Hefei & 3.0032 & 3.1691 \\
\hline 14 & Herbin & 3.9301 & 6.1178 \\
\hline 15 & Hohhot & 3.8602 & 2.0298 \\
\hline 16 & Jinan & 3.5228 & 4.0582 \\
\hline 17 & Kunming & 5.5992 & 3.3173 \\
\hline 18 & Nanchang & 4.4331 & 4.5307 \\
\hline 19 & Nanjin & 1.7734 & 2.7127 \\
\hline 20 & Nanning & 4.8280 & 0.4699 \\
\hline 21 & Ningbo & 2.6388 & 0.8185 \\
\hline 22 & Shenyang & 5.3802 & 6.6270 \\
\hline 23 & Shijiazhuang & 1.9582 & 1.2775 \\
\hline 24 & Tianjin & 3.7088 & 1.8164 \\
\hline 25 & Urumqi & 3.1028 & 2.9504 \\
\hline 26 & Xiamen & 1.1509 & 4.0083 \\
\hline 27 & Xi'an & 2.8219 & 3.7291 \\
\hline 28 & Xining & 4.5082 & 3.8677 \\
\hline 29 & Zhengzhou & 4.3456 & 4.4234 \\
\hline
\end{tabular}

8 We use the Akaike Information Criterion (AIC) and Schwarz Criterion (SC) to determine the ARIMA model orders in EI. Different cities have different orders of ARIMA. For example, the mode of Changsha is $\operatorname{ARIMA}(2,1,2)$, and Shenyang is $\operatorname{ARIMA}(2,0,3)$. 
1994; Hoesli, Lizieri, \& MacGregor, 2008; Lee, 2014), and unexpected inflation (UI) is computed by subtracting EI from AI (Bond \& Seiler, 1998; Gatzlaff, 1994). All indices are set at 1.00 for the first month of 2003 to eliminate scaling effects (Hoesli et al., 2008).

To determine if there is a co-integration relationship between HPI and EI, and between HPI and UI respectively, we apply the same ARDL/bound testing methodology as in the previous section. The F-statistics are reported in Table 5 and are compared with the critical values in Table 4.

The results are consistent with our previous findings, that is, there is no cointegration relationship between housing prices and different types of inflation. It is found that only the F-statistic of HPI and EI of one city (Beijing) exceeds the critical value at the significance level of 5\%. However, at the significance level of $2.5 \%$, the F-statistic values of all cities are less than the critical values.

\section{Conclusions}

In view of the regional variation of the real estate market in China, this paper uses the data on HPIs recently constructed by Fang et al. (2016), which are substantially different from other HPI indices in the prior literature examining Chinese real estate market, and data on inflation (represented by the consumer price index) in the 29 firsttier and second-tier Chinese cities for the 2003-2013 period to re-examine the long run relationship between house prices and inflation. Empirical analysis of unit root tests and the ARDL model bounds test in this study shows that there is no long-run relationship between housing prices and inflation in almost all of the 29 Chinese cities. Namely, there is no significant long-run transmission between housing prices and inflation. To check the robustness of our results, we divide actual inflation into expected and unexpected inflation. Further analysis on the relationship of housing prices with expected and unexpected inflations in 29 cities yields the similar results.

This finding is contrary to the conclusions of previous studies (i.e., Kuang \& Liu, 2015; Wu \& Tidwell, 2015; Yu \& Huang, 2016). This might be due to different data sources and methodologies. Furthermore, although housing prices cannot hedge inflation, our analysis shows that the aggregate growth rate of HPI is far higher than that of inflation. Thereby, the disproportionate growth of housing prices to CPI may be an indicator of a housing bubble (Christou et al., 2018).

Why is there no co-integration relationship between housing prices and inflation in China? The first reason is the composition of the CPI in China. Differing from that of other countries, the CPI of China doesn't include house prices in its construction, because investment in houses is regarded as an investment instead of consumption. According to $\mathrm{Lu}$ (2016), the cost of living represented 17.8\% of the CPI. It involves the cost of materials used in construction and decoration, rent, housing maintenance fees, property fees, interest on non-investment housing loans, utilities, and other housing-related services, etc. Among the list, the proportion of building costs does not exceed $50 \%$ of the living cost. That is, the cost of building construction in the CPI is expected to be no higher than $8.9 \%$. Meanwhile, the proportion of building cost does not exceed $40 \%$ of housing prices. The higher the housing prices, the smaller this proportion. As a result, the connection between house prices and inflation turns out to be weak.

Besides, investment in housing markets does not necessarily stimulate consumption as a whole. Most homebuyers use mortgage loans either because of limited purchasing power or because of the desire to use financial leverage to make investments. For some wealthy people, although it might seem that the rise in housing prices and the corresponding increase in disposable wealth can stimulate consumption, the impact on their consumption may be limited due to the low-income elasticity. For people who buy houses to live in, the wealth effect may not be significant partly because of the need to repay their loans and partly because of the underlying traditional Chinese consumption habits which makes them reluctant to borrow for spending (except for home purchases) despite their increased property wealth. For those who do not own a house, the housing price increases suggest that they will bear a heavier debt burden in the future because unlike people in Western countries, most Chinese would prefer to spend what they earn for most of their life in purchasing a home rather than renting a house. As a result, the obvious substitution effect of wealth may generate a crowding-out effect on their consumption. Overall, the wealth effect of rising housing prices on different groups of people in China may not be evident.

The conclusion made in this study has several implications for academicians and practitioners. Future researchers, when investigating residential real estate and inflation, should be more cautious in claiming the relationship between housing prices and inflation. For consumers and investors, they should understand that, although there is no co-integration relationship between housing prices and inflation, the aggregate growth rate of HPI is far higher than that of inflation, which imply that they could still make a fortune by investing in the real estate market when the market grows rapidly.

For policy-makers, the results of this study provide some implications. Given that there is no long-run relationship between housing prices and inflation, governments should adopt different monetary policies when adjusting inflation and housing prices. Second, in light of the surging growth of housing prices relative to inflation, governments should guard against possible bubbles in the real estate market. Third, the dramatic surge in China's housing prices for these years may have drawn a large amount of capital into the real estate industry, thereby reducing the inflow of funds into other industries, seriously weakening the development of the real economy. Therefore, governments should design relevant policies to rationally channel funds into the real economy and prevent excessive capital inflow into real estate market. 
Due to the lack of data, the relationship between inflation and the prices of other forms of real estate is not investigated. As price indices of the commercial real estate and industrial real estate may have different properties, whether they provide a good hedge against inflation and whether they are related to inflation still merit future research.

\section{Acknowledgements}

The authors are grateful to Professor Hanming Fang for providing the HPI data in 29 Chinese large cities. We thank the editor in chief, Audrius Banaitis, and two anonymous referees for their detailed and constructive comments.

\section{Funding}

This work was supported by the Fundamental Research Funds for the Central Universities (No. 2018CDXYJG0047).

\section{Author contributions}

Jianli Tang contributed to the conception of the study and performed the data analysis and wrote the manuscript. Kunhui Ye contributed to analysis and manuscript preparation. Yan Qian supported literature review. All authors have read and approved the final manuscript.

\section{Disclosure statement}

The authors declare no conflict of interest.

\section{References}

Ahuja, A., Cheung, L., Han, G., Porter, N., \& Zhang, W. (2010). Are house prices rising too fast in China? In IMF Working Paper (No. 10/274). Retrieved from https://www.imf.org/external/pubs/ft/wp/2010/wp10274.pdf

Amonhaemanon, D., De Ceuster, M. J. K., Annaert, J., \& Le Long, H. (2013). The inflation-hedging ability of real estate evidence in Thailand: 1987-2011. Procedia Economics and Finance, 5, 40-49. https://doi.org/10.1016/S2212-5671(13)00007-5

Anari, A., \& Kolari, J. (2002). House prices and inflation. Real Estate Economics, 30(1), 67-84. https://doi.org/10.1111/1540-6229.00030

Arnold, S., \& Auer, B. R. (2015). What do scientists know about inflation hedging? The North American Journal of Economics and Finance, 34, 187-214. https://doi.org/10.1016/j.najef.2015.08.005

Barber, C., Robertson, D., \& Scott, A. (1997). Property and inflation: the hedging characteristics of U.K. commercial property, 1967-1994. The Journal of Real Estate Finance and Economics, 15(1), 59-76. https://doi.org/10.1023/A:1007749305400

Bodie, Z. (1976). Common-stocks as a hedge against inflation. Journal of Finance, 31(2), 459-470. https://doi.org/10.2307/2326617

Bond, M. T., \& Seiler, M. J. (1998). Real estate returns and inflation: an added variable approach. Journal of Real Estate Research, 15(3), 327-338.
Christou, C., Gupta, R., Nyakabawo, W., \& Wohar, M. E. (2018). Do house prices hedge inflation in the US? A quantile cointegration approach. International Review of Economics \& Finance, 54, 15-26. https://doi.org/10.1016/j.iref.2017.12.012

Fama, E. F., \& Schwert, G. W. (1977). Asset returns and inflation. Journal of Financial Economics, 5, 115-146. https://doi.org/10.1016/0304-405X(77)90014-9

Fang, H., Gu, Q., Xiong, W., \& Zhou, L.-A. (2016). Demystifying the Chinese housing boom. NBER Macroeconomics Annual, 30(1), 105-166. https://doi.org/10.1086/685953

Fisher, I. (1930). The theory of interest. New York, NY: Macmillan.

Gatzlaff, D. H. (1994). Excess returns, inflation and the efficiency of the housing market. Journal of the American Real Estate and Urban Economics Association, 22(4), 553-581. https://doi.org/10.1111/1540-6229.00649

Glascock, J. L., Feng, L., Fan, L., \& Bao, H. X. (2010). Inflation hedging characteristics of real estate assets in Hong Kong. SSRN Electronic Journal, 301(1), 107-109. https://doi.org/10.2139/ssrn.1180658

Hoesli, M. (1994). Real estate as a hedge against inflation: learning from the Swiss case. Journal of Property Valuation and Investment, 12(3), 51-59. https://doi.org/10.1108/14635789410063913

Hoesli, M., Lizieri, C., \& MacGregor, B. (2008). The inflation hedging characteristics of US and UK investments: a multifactor error correction approach. Journal of Real Estate Finance and Economics, 36(2), 183-206.

https://doi.org/10.1007/s11146-007-9062-6

Hoesli, M., MacGregor, B. D., Matysiak, G., \& Nanthakumaran, N. (1997). The short-term inflation-hedging characteristics of UK real estate. Journal of Real Estate Finance and Economics, 15(1), 27-57. https://doi.org/10.1023/A:1007797221329

Huang, H., \& Hudson-Wilson, S. (2007). Private commercial real estate equity returns and inflation - new news on hedging power. The Journal of Portfolio Management, 33(5), 63-73. https://doi.org/10.3905/jpm.2007.698906

Ibbotson, R. G., \& Siegel, L. B. (1984). Real estate returns: a comparison with other investments. Journal of the American Real Estate \& Urban Economics Association, 12(3), 219-242. https://doi.org/10.1111/1540-6229.00320

Kuang, W., \& Liu, P. (2015). Inflation and house prices: theory and evidence from 35 major cities in China. International Real Estate Review, 18(1), 217-240.

Larsen, E. R., \& Sommervoll, D. E. (2004). Rising inequality of housing: evidence from segmented house price indices. Housing, Theory \& Society, 21(2), 77-88. https://doi.org/10.1080/14036090410034357

Lee, C. L. (2014). The inflation-hedging characteristics of Malaysian residential property. International Journal of Housing Markets and Analysis, 7(1), 61-75. https://doi.org/10.1108/IJHMA-10-2012-0053

Leung, A. (2010). Commercial property as an inflation hedge: an Australian perspective. Pacific Rim Property Research Journal, 16(1), 97-115. https://doi.org/10.1080/14445921.2010.11104297

Li, L. H., \& Ge, C. L. (2008). Inflation and housing market in Shanghai. Property Management, 26(4), 273-288. https://doi.org/10.1108/02637470810894902

Lu, S. (2016). Estimation of CPI component project weight and 2016 trend forecast. Bonds, 4, 58-60 (in Chinese).

Ma, L., \& Liu, C. (2008). Estimating impacts of consumer prices on house prices. In Proceedings of the 37th Australian Conference of Economists, Gold Coast, Queensland, Australia (pp. 1-16). Brisbane, Qld: Economic Society of Australia. 
Pesaran, M. H., \& Shin, Y. (1999). An autoregressive distributed lag modelling approach to cointegration analysis. In S. Strom (Ed.), Econometrics and economic theory in the 20th century: the Ragnar Frisch centennial symposium (pp. 371-413). Cambridge: Cambridge University Press. https://doi.org/10.1017/CCOL521633230.011

Pesaran, M. H., Shin, Y., \& Smith, R. J. (2001). Bounds testing approaches to the analysis of level relationships. Journal of Applied Econometrics, 16(3), 289-326. https://doi.org/10.1002/jae.616

Qiu, L. (2011). Analysis of real estate hedging inflation. Times Finance, 11, 182-183 (in Chinese).

Sing, T., \& Low, S. Y. (2000). The inflation-hedging characteristics of real estate and financial assets in Singapore. Journal of Real Estate Portfolio Management, 6(4), 373-385.
Wu, J., Gyourko, J., \& Deng, Y. (2016). Evaluating the risk of Chinese housing markets: what we know and what we need to know. China Economic Review, 39, 91-114. https://doi.org/10.1016/j.chieco.2016.03.008

Wu, Y., \& Tidwell, A. (2015). Inflation-hedging properties of regional Chinese real estate market: evidence from 35 cities in China. Applied Economics, 47(60), 6580-6598. https://doi.org/10.1080/00036846.2015.1080811

Yu, H., \& Huang, Y. (2016). Regional heterogeneity and the trans-regional interaction of housing prices and inflation: evidence from China's 35 major cities. Urban Studies, 53(16), 3472-3492. https://doi.org/10.1177/0042098015617882 